\title{
THE THEATER OF A LIBERAL IRONIST: THE AMERICAN WEST AND THE FEMALE SELF IN SHEPARD's A LIE OF
}

MIND

Muhammad Hossein Oroskhan, Shiraz University, School of Literature \& Humanities, h.oroskhan@gmail.com

Bahee Hadaegh, Shiraz University, School of Literature \& Humanities, bhadaegh@shirazu.ac.ir

Original scientific paper

DOI: 10.31902/fll.35.2021.2

\begin{abstract}
The formation and the establishment of the United States firmly adheres to two beliefs of the American dream and the American west. Though the American dream was part of American culture from its beginning, the other one became the driving force of American culture in the second part of the twentieth century when Sam Shepard began his career as a playwright. During this time, American theater emerged into a main arena for the presentation of the American west. Nevertheless, Shepard attempted to avoid playing with the duality of reality and illusion in his presentation of the American west when he put forward his characters to face and experience the world to then discover their selves. At the pinnacle of his success, he wrote A Lie of the Mind, a play that is filled with heroines who would leave the violent world of men to change their destinies. As such, Shepard endeavored to free their selves and flow them to experience a new world. Likewise, Shepard's contemporary American philosopher, Richard Rorty, believed in the importance of self and the necessity of its redescription to create his ideal society. However, hopeless to find a philosophy model, he lends to literature to find his liberal ironist. On this account, the following study is not only to provide Sam Shepard as a liberal ironist in Rorty's term but also to reveal certain puzzling features in Shepard's A Lie of Mind, not least of which is the reason why his female characters blow the world of the American west to search for a new world.
\end{abstract}

Keywords: American west, Cowboy, Female self and Liberal ironist.

\section{Introduction}

The number of American authors who have dealt with American west is noticeable, however, no one has delved into the American west more than Sam Shepard who claims that "cowboys are really interesting to me-these guys [...] took on this immense country and didn't have any 
real rules" (Chubb et al. 190). Immersing herself in American west, Shepard has been called "the poet laureate of the American West" (Coe 1980:122). Shepard's fascination with the significance of cowboys in American west is readily revelatory even from the title of his one-act plays like Cowboys, in which he often tried his hand in "reinventing one's identity" (Crank 20). Indeed, cowboys occupy an essential place in Shepard's mind whenever he needs to have a basis to build "the idealization of American identity" (Madachy 23). For him, American identity is closely correlated with the American west and through extensively exploring this factor, he has been called "a conduit that digs down into the American soil and what flows out of him is what we're all about" (qt. in Kroll, Guthrie, and Huck 1985: 71). Nevertheless, he is rather uncertain about the depiction of the west when he portrays it as "welcoming and menacing, unequivocal and unfathomable, redemptive and ruinous" (Westgate 728). Needless to say that examining the contradictory presentation of American west is common to all critics' attempts which address the issue. Already, scholars ${ }^{1}$ like Richard White have noted that "the imagined West is the work of professional writers, journalists, and filmmakers who are often located outside the West itself or in that peculiar comer of it, Hollywood" (615) and how "a myth about the West becomes a story that explains who westerners and who Americans are and how they should act" (616). Ensuing from this perspective is the view that the constructed image is far away from the realities of the west and more close to a mythical interpretation of the west to be shown on the silver screen or occupy the book markets of fictional writings. Nevertheless, the originality of Shepard's view lies in its unprecedented perspective toward studying this image. Shepard believes that we are "being seduced into believing one image and we prefer the image to the human being, we'd rather watch you on television and talk to you" (Jacoby). Later on, Shepard tries to demystify the myth of American west but not to establish a new myth for American west. When he proclaims that "myth is a lie of the mind" (Rosen), he implies the point that his attempt is not to focus on identifying a perfect image or the true myth of American west but to follow the elusive nature of American west in present time and release it from the shackles of myths. As such, he emphasizes on this point that "myth in its truest form has now been demolished" (Rosen), and the notion of American

\footnotetext{
${ }^{1}$ Douglas R. Nickel in "Art, Ideology, and the West", James P. Ronda in "Passion and Imagination in the Exploration of the American West" and David M. Wrobel in "The Literary West and the Twentieth Century" are among those following the same point of view.
} 
west should be studied not with regard to discovering its true myth. However, this should be noted that Shepard is never disagreeing with other critics over recognizing the mythological or false image of American west when in fact, in the case of the cowboy, he grapples with the notion that the shining cowboy is by default assumed quite falsely with certain features that have propelled him to iconic status in American western culture. The accumulation of these images have led to the appearance of "a century of American children grew up imagining themselves to be cowboys" (White 613) and moreover, the consequent adoption of "a store of metaphors of violent conflict and confrontation that became, along with sports metaphors and sexual metaphors, basics of male popular speech" (613). However, Shepard's method is to prepare his characters to act toward the world and if his male characters are impotent to face the world ${ }^{2}$; Shepard is concentrated on his female characters in his A Lie of Mind. The last play is often regarded as his best work for the stage. Shepard himself has considered it "better than even Buried Child, which won the Pulitzer" (Crank 289). Besides, with regard to this play, Shepard claimed that he's been struggling to understand "what is it like to embrace the female part of yourself that you historically damaged for one reason or another?" (Crank 14). Related to this issue, our study is riveted not only on exploring the female parts of female characters but also to firstly study why cowboys' views of women are significantly distorted and stereotypically shaped and why they are not giving themselves the chance of embracing women fully and comprehending the diversity of the roles that they can play in the community.

The play depicts excessive male violence, which can be considered as Shepard's critique of the existence of violence in the inherent nature of the American west. The resultant violence is influential on men's perspective of women with whom they are living. As such, if a woman is out of their stereotypical categorization of the good girl such as the schoolmarm or the rancher's daughter or the bad girl such as those always in brothel and dance hall that they will reach

\footnotetext{
2 The closure of Shepard's True West, the last play in his famous family trilogy, when two brothers are desperately facing each other but not able to move or challenge the world imply this point. The aforementioned play has been written before A Lie of Mind. Moreover, Sandra Wynands in her article "Sam Shepard's Anti-Western Silent Tongue as Cultural Critique" refers to Shepard's male characters as "alcoholics, desperate fathers, maniacs, and good-for-nothings, aimlessly wandering about the pampa rather than purposefully settling and cultivating the continent" (308).
} 
an impasse in interacting with them (Rushing 17). Thus, Shepard's central aim is to demolish the cemented fact and fiction regarding the notion of the American west and prepare the self to face and experience the world. If writing for Shepard is "a journey into the mystery of the self and mapping these states of consciousness" (Grant 553), then his A Lie of the Mind is the discovery of female self which are in relation with the cowboys "that captured the whole 80's and painted an outstanding picture of themselves in the popular culture" (Rushing 14). Being so, Shepard can aptly be deemed as a liberal ironist in Rorty's term. The isolation of subjective thought that can persistently result in a new gesture since the individual is ever allowed to question his status is also what fascinated Richard Rorty as a postmodern philosopher. For Rorty, having the "talent for speaking differently, rather than for arguing well, is the chief instrument of cultural change" (Rorty 7). For him, this is not possible in the world of philosophy as in philosophy, constant arguing is always done to achieve one result whereas developing the ability to speak differently creates the chance of having endless possibilities for the self to recreate itself again and again. Inevitably, Rorty's liberal ironist avoids being stagnated in one fixed mindset and flows freely to redescribe himself for a better goal and purpose since "redescription is a powerful tool for getting out from under stultifying final vocabularies" (Frazier 9). More importantly, Rorty finds his great examples of liberal ironist among literary authors. Thus, this research will consider Shepard as a liberal ironist who focuses on escaping the constructed world of the American west and opening his audience's eyes to a new world through which they can see the spontaneous flowing of one's experience. It is from this point that for his female characters in A Lie of the Mind, this new world is created even at the cost of blowing the old world for the search of a new world in which gender equality has a better chance of being expressed to the members of the community.

\section{Sam Shepard: American Liberal Ironist}

"America is not a land or a people: France was a land, England was a people, but America, having about it still that quality of the idea" (Turnbull 183). The ideas driving this country forward are the American dream and the American west; the promise of the first one attracted people globally, and the curiosity of the latter shaped the American identity. The significance of these two ideas is enormous and prevalent in American lives primarily American west that a cursory reading of American cultural products would attest to the fact that "no other phenomenon in United States history has generated more storied events and characters than the settling of the West" (Wade 286). On the 
other hand, the American dream is hugely embedded in every aspect of the American people including "images both of the nation within the world and of the individual within the nation"(Jillson 17). Nevertheless, the debate over these ideas in America has never been limited to their positive impact on American lives; for Sam Shepard, it has frequently become a debate over proving their hindrance to the progress of people's lives. To show the corrosive trend that these ideas sap at the roots of American people's lives, Shepard recruits a rigorous attempt to understand the nuances through which the self is explicitly constructed concerning these two ideas. Coincidentally, the rise of Shepard to fame and the tendency of critics to notice the peculiarity of Shepard's theater can be appropriately related with the publication of his works at the most appropriate time, which means the moment that these ideas were not running the engine of American lives properly. The time that America was lagging in its history was during the presidency of Jimmy Carter that the great image of America was shattered considerably in the eyes of people due to domestic and foreign matters (Strieff 172). On this account, Shepard's plays opened up a new terrain for critical analysis of these two ideas and, more specifically American west. Soon, he was welcomed warmly by American critics to be leveled with "such great figures like Woody Guthrie and John Steinbeck" (Wade 298). This being the case, Shepard's grand status as the poet laureate of the west sounds reasonable as he got into the heart of this matter and conveyed "the cultural nostalgia of the 1980s and its appetite for long-held attitudes toward American character and promise" (Wade 298). Therefore, Shepard's attempt of achieving "a sense of a sudden liberation, a sense of flow, of play, of freedom from time and space limits, a sense of sudden growing transformation" (Grant 122) would be considered as an appropriate response to the desiccated image of these two ideas and can gain him enough qualification to be considered a liberal ironist in Rorty's term.

Richard Rorty as one of the postmodern vanguards of the $20^{\text {th }}$ who was concerned with the significance of self and its construction, proclaimed the urgent need of a liberal ironist as an ideal type for the self. In his view, liberal ironist is only to be located in literary works. His prioritization of literature over philosophy by proposing the model of liberal ironist is first broached in his phenomenal book entitled Contingency, Irony, and Solidarity (1989) that includes his lectures during the 80s. What Rorty's perspective elides is the fact that the significance attached to the concept of philosophy should be disregarded since it is dispensed with finding the truth. In this respect, comments Rorty, philosopher's attempt through history at finding the 
truth is nothing more than a development of "epistemological behaviorism that explain[s] rationality and epistemic authority by reference to what society lets us say" (Rorty, Philosophy 174). By pointing to the fallacy of epistemological behaviorism, Rorty is indeed deducting the task of object analysis from philosophy by introducing it into the conversation of social practices in which the solidarity of human beings is of prime importance. At this stage, Rorty's thinking lends considerable pervasiveness to literature in which the literary author is never after crystallizing a single truth to the reader, for in his mind, authors like "Cervantes and Shakespeare began to suspect that human beings were, and ought to be, so diverse that there is no point in pretending that they all carry a single truth deep in their bosoms" (Rorty 93). Rorty's distinction between literature and philosophy is well absorbed in Marek Kwiek's comments that reflect Rorty's attempt of renewing philosophy to make it recognize that "the world is ambiguous; that there is no single, absolute truth but a multitude of relative and contradictory truths. Rorty would like to accept Kundera's "wisdom of uncertainty" (201) and shift his focus on literature since philosophy is rendered without the nature of truth to discover and propagate in the society when in fact there is no truth in society anymore. Therefore, Rorty as a philosopher never confirms philosophy as the suitable platform on which this problem is to be solved whereas considers "genres such as ethnography, the journalist's report, the comic book, the docudrama, and, especially, the novel" (Contingency xvi) as the tentative platform to this study. He dispels the notion that you can achieve an ideal society when its members are always trying to meet a set of criteria, but simultaneously, its members are driven by "imagination, the imaginative ability to see strange people as fellow sufferers" (xvi). For Rorty, achieving this type of society may be theoretically easy but in reality, it demands the legitimation of the needs of self-creation as crucial as human solidarity. For this purpose, Rorty sketches an especial type figure named "liberal ironist" (xv). Afterward, his attempt ends in assuming a liberal ironist under three conditions:

(1) She has radical and continuing doubts about the final vocabulary she currently uses, because she has been impressed by other vocabularies, vocabularies taken as final by people or books she has encountered; (2) she realizes that argument phrased in her present vocabulary can neither underwrite nor dissolve these doubts; (3) insofar as she philosophizes about her situation, she does not think that her vocabulary is closer to reality than others, that it is in touch with a power not herself. Ironists who are inclined to philosophize see the choice between vocabularies as made neither within a neutral and universal 
meta-vocabulary nor by an attempt to fight one's way past appearances to the real, but simply by playing the new off against the old. (73)

The central point dictated by Rorty is that his liberal ironist acquires necessary qualifications not by philosophers or political scientists but instead by literary authors. His view of liberal ironist was primarily presented by "the private goals of self-creation and redescription within the context of an acute awareness of the contingency of their belief system" (Foley 20). Already noticed, the American belief system has been shaped by the American dream and the American west and Shepard's chief aim is intended to open this world for the audience and disclose to them the Pandora's box of these two ideas and later how the self is influenced by these two ideas. Explicitly, he refers to his purpose of theater that can concurrently illuminate this point: "What I'm trying to get at here is that the real quest of a writer is to penetrate into another world. A world behind the form. The contradiction is that as soon as that world opens up, I tend to run the other way. It's scary because I can't answer to it from what I know". (qtd. in Marranca 217)

His words are revelatory, for he never settles one goal to be achieved; he just opens the doors of new worlds for his audience, not considering how unsettling and uncertain it might be. This being the case, Shepard serves the self as the premise with which the connection should be made. Relevant to this discussion, Gary Grant, in two prominent articles, minutely studied Shepard's technique of writing by highlighting the importance of self in his theater. In his view, Shepard's theater tended toward "the rapid shifts of awareness and the sensations of the experience in writing" (550). Grant hails it as the "performance of the self'. Striking this point would be Grant's examination of Shepard's theater; still, he believes that Shepard's self is catapulted to the geographic location or as he sums it up; "Shepard's life is the concept of the self watching the self perform in a particular environment" (553). In his other article, he draws on a parallel study by citing a physicist who has discussed a theory called "dissipative structure" and relating to Shepard's theater. The seeds of this research germinate the point that like dissipative structures, Shepard's theater is "a flowing wholeness that is highly organized but always in process" (123). Shepard's focus on self-creation is also considered by other critics like Herbert Blau as a "racing self-destruction ... careening wildly toward some deeply unutterable end" (524). Though the latter one is negatively referring to the significance of self in Shepard's theater, both of their studies have brought to the fore the emphasis on self-creation. As such, noticing the emergence of the same perspective in other fields like philosophy may 
not be an act of coincidence but a serious attempt to address the issue appearing in American lives. Subsequently, each field can complement the other in enhancing the understanding of the issue. Likewise, Rorty's liberal ironist covers the perspective that that self undergoes the unfavorable act of self-creation resulting in losing the basis from which one used to express him/herself and suggests that "one's self and one's world are futile, obsolete, powerless. Redescription often humiliates" (Contingency 90). Rorty's last sentence is pivotal in grasping the negative aspect of self-creation. He asserts that when human beings are navigated through their lives by cherishing their values and beliefs, any growing doubt leading to defying their beliefs and values will humiliate them before other people. As such, "the liberal ironist just wants our chances of being kind, of avoiding the humiliation of others, to be expanded by redescription" (91). Therefore, Rorty's ideal society is based on the "susceptibility to humiliation" (91) and what appears radically different concerning any other sort of existing solidarity among the individuals of a society is that Rorty's sense of "human solidarity is based on a sense of a common danger, not on a common possession or a shared power" (91), this means always being prepared to redescribe yourself and never try to attach yourself to a central power that has already been labeled as right, true or justified. In Rorty's society anyone can see his/her self without being destructed by any external force. In another word, "the hope that one's world-the little things around which one has woven into one's final vocabulary - will not be destroyed" (92). In the same vein, furthering the study, some other aspects of Shepard's theater for the notion of the self will be revealed by more focusing on his A Lie of Mind.

\section{Shepard's Lie of Mind: Cowboys and Women}

From his first-act plays to his famous family plays and often neglected plays like States of Shock and God of Hell, Shepard follows the construction of the cowboy, the exemplary symbol of the American west, regarding the array of external factors yet avoiding capturing an image for his cowboy. He endeavors to shatter the already cemented image of the American west by the cultural atmosphere of the midtwentieth century that begotten the American beloved cowboy. Drawing from the constructed viewpoints of cowboy is his stereotypical interactions with women that dwell on two views of women; one is described by the "bad girl" spending time in the brothel or dance hall, and the other one is the typical "good girl" as the schoolmarm or the rancher's daughter (Rushing 17). Though "women's liberation movement of the 1960s and 1970s has delivered a considerable blow to 
the Western myth" (23), Shepard attempted to succinctly hang on the same issue in his way in A Lie of Mind. Play's first appearance encountered harsh criticism of feminists like Lynda Hart describing it as a play ameliorating male violence by placing it "within the context of romantic ideology" (73). Nonetheless, Shepard while admitting the male violence exposes its mythical construction and how they are shoved into certain clichés without liberating lightness and as a result, Shepard provides women with a liberating moment in his play.

A Lie of Mind begins with a telephone call between two brothers, an echo from Shepard's previous play True West that drove with the different lifestyles of two brothers but in A Lie of Mind, the story soon spurs on a different direction when Jake tells off Frankie about beating his wife to death. Though, no assurance is received of the death of Jake's wife, Beth is showed being hospitalized and just regaining his consciousness while repeating, "Am I a mummy now? Am I a mummy? Am I? Am I now?" (Shepard 4). The coincidence of Jake's thinking of having killed his wife is followed by his wife thinking of being a mom or, in other words giving birth to a child. Shepard's simple juxtaposition of these two incidents incites the audience to seek a cause and effect link between these two incidents or at least how the eruption of the violence on one side may lead to the emergence of life on the other side. As such, Shepard is opening his play by metaphorically referring to the vicious cycle of life in the American west, that violence is incidentally produced in successive generations. Moreover, later on, the reason behind Jake's excessive violence is determined to be his suspicion that his wife has been cheating on him when playing her role in theater. As such, one can readily attribute Jake's behavior to his deep-rooted thinking in stereotypical cowboy categorization of women; be the good wife by staying at home or playing the bad girl outside of the house whatever the occupation may be. As in his dialogue with his brother, Jake confesses that he is unable to believe what his wife has been recurrently telling him that she has been playing her role and not doing it in real life; JAKE: Yeah. The character. That's right. They start acting that way in real life. Just like the character. Walkin' around-talkin' that way. You shoulda seen the way she started to walk and talk. I couldn't believe it. Changed her hair and everything. Put a wig on. Changed her clothes. Everything changed. She was unrecognizable. I didn't even know who I was with anymore. I told her. I told her, look-"I don't know who you think you are now but I'd just as soon you come on back to the real world here". And you know what she tells me? (10)

Jake's contentious point with his wife is regarding the possibility or impossibility of playing different roles in life; while his wife believes 
in the possibility of different roles, Jake is divested of imagining such a possibility. Jake's view of women is stuck with two images of good girl and bad girl and he finds it almost impossible to imagine women playing any other role in the society. Beth's acting in the theater is riveting for him. In addition, when Beth is referring to this acting to be "more real than the real world" (10) since she is finally able to get rid of the cliché role that she was supposed to play, Jake is shocked and attempts to beat her to death. On the other hand, Jake's losing Beth becomes tragic for him in as much as he says that "it turns to a fear for my whole life. Like my whole life is lost from losing her. Gone. That I'll die like this. Lost. Just lost" (14). It might well refer to how Jake is craving for fostering a solidarity with Beth but suffering from his inability, a feature that is generally observed in the mythical construction of the cowboys. The same feeling is expressed by Beth when she talks back to her brother by saying it out loud that "HEEZ MY HAAAAAAAAAAAAAAAART!!! (20)". To this part, Shepard has clarified the issue lying behind the life of a western couple, more specifically women's suffering in this relationship but if the play is to be the work of a liberal ironist, the necessary conditions should be specified. As such, the ironic perspective is provided when Shepard is showing Jake's inability to see the contingency of his beliefs since he is unable to get along with the new situation of his wife. Secondly, the portrayal of pain in sounds rather than the language. In Rorty's viewpoint, "pain is nonlinguistic: It is what we human beings have that ties us to the nonlanguage-using beasts. So victims of cruelty, people who are suffering, do not have much in the way of a language" (Contingency 94) and in the same manner, Beth's suffering of the pain is conveyed not verbally but through sputtering as Beth is heard recovering in the second scene creating such sounds as "BETH: "Saahthah-Jaah-thuh-saah-saah-saah-saah ... Ghaah-ghaahkhaah-khaah-khaah" (4).

Exploring the misery of western women is at the center when other women, Jakes' mother, and sister, get on the stage. Lorraine, Jake's mother, commences talking about Jake's violence by relating it to an incident at his birth time "he was trouble from day one. Fell on his damn head the second he was born. Slipped right through the doctor's fingers. That's where it all started. Back there. Had nothin' to do with his upbringing" (22). The audience can readily feel the irony hidden here. Jake's matter lies directly with his upbringing, which included being constructed through mythical west rather than being ridiculously related to an incident at his birth. Soon after that, Jake's mother tries to get close to Jake and calms him to forget his terrible memory of Beth. Nevertheless, the audience will more notice how women's perspective 
is constructed in the west when she begins talking about another woman:

Lorraine: You musta lost a good thirty, forty pounds. A woman ain't worth that kind of a loss. Believe you me. There's more pretty girls than one in this world. Not that she was such a looker... You'll find someone else sooner or later. (33)

The superiority of masculinity is prevalent in the west that women are forced to live with the atmosphere and carries this view automatically like Jake's mother when she is performing it unquestionably. In another word, Lorraine tries to play the role of a good caring woman here by attending to the basic needs of Jake. However, her attempts are aborted when Jake refuses to eat the soup that she is serving him: "Jake suddenly knocks the spoon out of her hand and sends it flying... holds the bowl high above his head and sends it crashing down on the mattress" (35). Playing with food is a recurring image in Shepard's plays that is noticed in some critical moments when his characters are dealing with frustration or no communion (Whiting, 182). Consequently, failure in expressing a sense of solidarity is what the image of food carries for Shepard. Seemingly, Shepard is divesting his characters of societal norms and behaviors to denigrate them to animalistic features, bonding together for the sake of providing each other's basic needs. The scene is clearly regarded as a background for the upcoming events showing the dysfunctionality of the familial relationship between Jake and her mother. Then, in a flashback, Lorraine reveals her past with his husband to Jake. She expresses her regrets over believing Jake's father on being in a mission whereas in reality he had been spending his time with different girls. Nevertheless, Lorraine's remembrance of the past discloses the role of a system in which he had difficulty with his husband; "You-Name-It-U.S.A. Those were the days we chased your daddy from one air base to the next" (Shepard, 36). Afterwards, their argument swiftly moves toward a conversation over the things left from Daddy. An American national flag along with a box filled certain items is handed to Jake by his mother as the representative of his father's days and when Jake asks her mother about the reason behind still keeping it, she says; "couldn't figure out where else to put it. Couldn't stand lookin' at this stuff anymore and I was afraid to throw it away" (38). Explicitly the shadow of the past is still controlling Lorraine and even Jake since he is shown at the stage to be mesmerized by the martial medals and the American national flag and seems to be drowned in the glory of the past. Janet V. Haedicke believes that "Jake's father personifies the monolithic masculinism which encodes meanings or inscribes 'Truths' (870). That explains why Jake still attempts to stick to the old truth associated with 
the sense of the American dream itself. Therefore, it is no wonder if the destruction of Shepard's Midwestern family is to be related to the demise of the American dream.

The next time Jake is on stage, he is with the other female member of his family, his sister. Sally begins arguing with Jake on how the family has been shattered; "I was just - I was driving around the house. In circles. Real slow. I couldn't make up my mind" (Shepard 60). Sally has been attempting to find meaningful existence in her life but each time thwarted and seeing her desires and hope disappear into the air, ergo befuddled by the situation and done talking to Jake, she gets close to Lorraine for having a communication. In a turn of events, we notice how Sally is trying to calm Lorraine by serving him soup, even though, it is readily rejected by Lorraine which again conveys the point of not having a base of communication. Then their argument leads to a revealing fact when Lorraine says, "Where is the humiliation supposed to end?" (86). Reaching this point is precisely what Rorty proposed as the basis of his ideal society; to avoid others' humiliation. In a similar spirit, Lorraine and Sally decide to follow a different route by ceasing to doubt or regret the pillars of the society in which they live. From this pivotal moment on, the two struggle to free themselves from this sort of humiliation afflicted on them by men. As such, wearing their new lenses, they seem to put aside arguing over their status in this maledominated society. Lorraine's first step is to burn the old photos and suggest to take on a long journey to Ireland to meet some old relatives and friends. What matters to them right now is not the destination but the purpose of leaving the past behind and reaching a new point in life or in Rorty's term to play the new off the old world by firing the house and leaving it burning to demolish a past and open up a new chapter in their lives;

LORRAINE: Nah-maybe we won't run. Maybe we'll just stand out there on the front lawn, the two of us, and watch it burn for a while. sing a song maybe. Do a little jig. Then we'll just turn and walk away. Just walk.

SALLY: Well, we're not gonna have any place to come back to, Mom. LORRAINE: Who's comin' back? (61)

As manifested above, their main aim is to untangle themselves from the old world and welcome the new world regardless of its outcome because the expansion of their selves is greatly restricted with the male's world that they are forced to leave it. Simultaneously, Jake, bereft of his female companions, is reborn from the burning fire like a phoenix but wrapped up in "American flag between his teeth and 
stretched taut on either side of his head, like a set of driving reins for a draft horse" (120). Jake's reappearance on the stage is at a different setting when Jake is his on knees and in total submission to Mike, Beth's brother. Before the house being burnt, Jake had the support of his mother and sister; nevertheless, as soon as they disappeared and his world got empty of a sister to cover him up or a mother to serve him, he now seems to be redescribed and his appearance in the other house clarifies his redescribtion when he passively surrenders himself to Mike's violence. Coincidentally, Jake is redescribed and humiliated in a system in which he had been brutally beating his wife; "the flag with which his country awarded his dead father's military mindset and in the spirit of which he rendered his wife 'red and black and blue'"' (Haedicke 91). Nevertheless, when Mike informs Beth of Jake's presence and considers it as a suitable time to take revenge, Beth answers back surprisingly that "he's dead" (121). Afterward, Mike tries to force Beth to meet Jake but is rebuffed by Beth who says, "No! You make-you make a war. You make a war. You make an enemy. In me. In me! An enemy. You. You. You think me. You think you know. You think. You have a big idea" (45). Beth is openly criticizing Mike for creating the same violence in her and how he is trying tries to transmit his evil male side to her. Beth's refusal can be ascribed to her sensitivity to other's humiliation, the concept was basically lacking in Jake or Mike's world. In other words, Beth is never using the supposed shared power to inflict violent act on Jake and later on, her attempt is centered on redescribing the society of male violence-oriented. When she is communicating with Frankie, she considers pretending changing roles to continue up in this world:

Beth: Pretend. Because it fills me. Pretending fills. Not empty. Other. Ordinary. Is no good. Empty. Ordinary is empty. Now, I'm like the man. (Pumps her chest up, closes her fists, sticks her chin out and struts in the shirt.) Just feel like the man. Shirt brings me a man. I am a shirt man. Can you see? Like father. You see me? Like brother. (She laughs.) (75)

Beth's ridiculous solution actually seems to be feasible because of its audacity of shattering the old roles and providing some new ones for women as her suggestion is brought up when she has been just mentioning that the relationship between her mother and father is deprived of having love. This may seem as like a plausible reason to explore a new relationship between herself and Frankie as she asks him to be a better version of his brother; "Your other one. You have his same voice. Maybe you could be him. Pretend. Maybe. Just him. Just like him. But soft. With me. Gentle. Like a woman-man" (76). In this respect, she believes that if Frankie can redescribe himself, they can genuinely fall in 
love. Moreover, this point should be made that Beth possibly imagines something as Rorty's ideal society in which human beings, regardless of their genders, can freely redescribe themselves and to be unhinderedly fitted into new situations. Nonetheless, the other significant point is regarding the moment when Mike is blamed for desecrating the American flag as he is wearing it nonchalantly around his rifle. Suddenly, the familial struggles are replaced with nationalistic struggle when Baylor berates Mike and declares, "It's not just a flag. That's the flag of our nation. Isn't that the flag of our nation wrapped around that rifle? (124). The important point is that Baylor feels the need to respect the flag but is not sure whether this is the right flag or not and when he continues raising the issue, he is still doubtful whether the shape of the flag has changed or not "They haven't changed it, have they? Maybe added a star or two but otherwise it's exactly the same. How could you not recognize it?" (124). Shepard's plays are always tainted with an image of "past with the acknowledgment of its dreadful power" (Schvey 25). Baylor upholds and cherishes the tradition of folding the flag correctly, though not noticing that he is automatically manipulated by the past. Manifested in his behavior is the respect for the national flag or the shared power and how anyone should defer to it. Then beside being dubious about the right way to perform this tradition, he gets a strange feeling and kisses Meg by getting close to her:

MEG: I believe that's the first time you've kissed me in twenty years.

BAYLOR: Aw, come on, it ain't been that long. Let's go on up to bed now.

BAYLOR: Well, I'm goin' up. You shut the lights when you come. And don't dawdle. I don't wanna get woke up in the middle of a good dream. (130)

Amazingly, this erotic and peaceful moment toward Meg occurs when they are immersed in the American dream. This clearly shows the difference between Meg and Baylor in finding and not finding truth in the American dream. The vivid American dream is blurring for Meg. On the other hand, Baylor is captured in a moment "when the domination of American reality by the dream machine seems like an amendment to the Constitution" (Blau 521) and he unwittingly seems to be navigated by this machine, yet Meg, customarily of Shepard's women character in this play, never acts like Baylor and turns down to go upstairs with him and prefers to watch the burning fire ignited by Sally and Lorraine; "MEG: (Still with hand to her cheek) Looks like a fire in the snow. How could that be?" (Shepard 131). Even though it is impossible since the 
houses are too far away, Shepard makes it appear possible to convey the message to the audience that women from this house also wish the same solution to their problem, burning and leaving behind the entangling past and presence to achieve a better and new future. Likewise, in this house, a mother and a daughter are suffering the same problem. Ascertained of this fact, they defy western men's treatment by imagining to leave them behind. Relevantly, this can be mentioned that Rorty used the pronoun 'she' to distinguish his type of person and her uniqueness as to imagine her liberal ironist in an entirely new society not already built and constructed by man and not to wonder that Shepard's women characters are moving in the same line.

\section{Conclusion}

Jane Kramer, a journalist for the New Yorker, published an intriguing narrative from a cowboy's life. Entitling the account, The Last Cowboy, he referred to the life of a rancher living in Texas. He described a cowboy regretting his life for not being like "John Wayne in Chisum, or Chill Wills in The Rounders" (White 615). Kramer sharply pointed to the fallacy shaped this person's mind and to what extent his life is driven by the "powerful cultural image of the West" (615). This cowboy is living while embedded with inconsistency in his mind of what a cowboy is and not arriving at a concrete definition, he subscribes to the imagined one constructed by a cultural machine-like Hollywood. Incidentally, the cowboy is unable to form his platonic world and notices his impotence to achieve the dream or to change his reality. In this process, an extra poignancy is added to cowboy's relation with women mainly when he is driven by the stereotypical image of women. Shepard recognizes the energy flowing through the cowboy but simultaneously acknowledges how it is dominated systematically and stereotypically. Shepard has been striving to tap into the nuances of this life ever since he began writing his play but in Lie of Mind, the story is shifted toward women; in other words, he has avoided redressing the issue but focusing on his female characters. As a liberal ironist in Rorty's term, Shepard follows her female characters through their self-creation and when his characters are confronted with the impasse of humiliation and the final negation of the promise they held, they will revolt and leave behind the ravaged society to start a new life.

\section{Works cited:}

Blau, Herbert. "The American Dream in American Gothic: The Plays of Sam Shepard and Adrienne Kennedy." Modern Drama, vol. 27, no. 4, 1984, pp. 520-539., doi:10.3138/md.27.4.520. 
Chubb, Kenneth et al. "Metaphors, Mad Dogs and Old Time Cowboys: Interview with Sam Shepard." American Dreams: The Imagination of Sam Shepard. Ed.

Coe, R. "Saga of Sam Shepard." New York Times Magazine, November 23: 569, 118, 120, 122, 124. 1980.

Crank, James A. Understanding Sam Shepard. University of South Carolina Press, 2012. Dyne, Sarah A. 2012.

Derevell, William Francis. A Companion to the American West. Blackwell, 2004.

Foley, Andrew. "Courageous Pessimist: An Interview with Athol Fugard." New Contrast, vol. 22, no. 4, 1994, pp. 63-69.

Frazier, B. Rorty and Kierkegaard on Irony and Moral Commitment: Philosophical and Theological Connections. Palgrave Macmillan, 2016.

Grant, Gary. "Writing as a Process of Performing the Self: Sam Shepards Notebooks." Modern Drama, vol. 34, no. 4, 1991, pp. 549-565., doi:10.3138/md.34.4.549.

---. "Shifting the Paradigm: Shepard, Myth, and the Transformation of Consciousness." Modern Drama, vol. 36, no. 1, 1993, pp. 120-130., doi:10.3138/md.36.1.120.

Hadicke, Janet. '“A Population [and Theater] at Risk': Battered Women in Heney'sCrimes of the Heartand Shepard'sA Lie of the Mind." Modern Drama, vol. 36, no. 1, 1993, pp. 83-94., doi:10.3138/md.36.1.83.

Hart, Lynda. "Sam Shepard 's Pornographic Visions." Studies III the Literary Imagination, vol. 21, no. 2, 1988, pp. 68-79.

Jacoby, Oren, director. Sam Shepard: Stalking Himself. Sam Shepard: Stalking Himself, 1998, www.youtube.com/watch?v=Dk51mNH5CFY.

Jillson, Calvin C. The American Dream: in History, Politics, and Fiction. University Press of Kansas, 2016.

Kroll, J., Guthrie, C., and Huck, J. "Who's That Tall Dark Stranger?" Newsweek, November 11: 68-74. 1985.

Kwiek, Marek. "After Philosophy: The Novelist as Cultural Hero of Modernity? On Richard Rorty's New Pragmatism." Theoria, vol. 45, no. 92, 1998, doi:10.3167/004058198782486019.

Madachy, Paul Seamus. 2003, pp. 1-239.

Marranca, Bonnie. American Dreams: the Imagination of Sam Shepard. PAJ Publications, 1993.

Rorty, Richard M. Contingency, Irony, and Solidarity. Cambridge U.P, 1999.

---. Philosophy and the Mirror of Nature. Princeton University Press, 2018.

---. Philosophy as Cultural Politics. Cambridge University Press, 2007.

Rosen, Carol. "'Emotional Territory': An Interview with Sam Shepard." Modern Drama, vol. 36, no. 1, 1993, pp. 1-11.

Rushing, Janice Hocker. "The Rhetoric of the American Western Myth." Communication Monographs, vol. 50, no. 1, 1983, pp. 14-32., doi:10.1080/03637758309390151.

Schvey, Henry. "A Worm in the Wood: The Father-Son Relationship in the Plays of Sam Shepard." Modern Drama, vol. 36, no. 1, 1993, pp. 12-22., doi:10.3138/md.36.1.12. 
Shepard, Sam, and Joseph Chaikin. A Lie of the Mind: a Play in Three Acts. The War in Heaven. Plume Book, 1987.

Strieff, Daniel. "FLAG and the Diplomacy of the Iran Hostage Families." Diplomacy \& Statecraft, vol. 28, no. 4, Feb. 2017, pp. 702-725., doi:10.1080/09592296.2017.1386465.

Turnbull, Andrew. Scott Fitzgerald. Vintage, 2004.

Wade, Leslie A. "Sam Shepard and the American Sunset: Enchantment of the Mythic West." A Companion to Twentieth-Century American Drama, 2007, pp. 285-300., doi:10.1002/9780470996805.ch18.

Westgate, J. Chris. "Negotiating the American West in Sam Shepards Family Plays." Modern Drama, vol. 48, no. 4, 2005, pp. 726-743., doi:10.1353/mdr.2006.0039.

White, Richard. It's Your Misfortune and None of My Own: a New History of the American West. University of Oklahoma, 1993.

Whiting, Charles. "Food and Drink in Shepard's Theater." Modern Drama, vol. 31, no. 2, 1988, pp. 175-183., doi:10.3138/md.31.2.175.

Wynands, Sandra. "Sam Shepard's Anti-Western Silent Tongue as Cultural Critique." Canadian Review of American Studies, vol. 35, no. 3, 2005, pp. 299-314., doi:10.3138/cras-s035-03-03.

\section{TEATAR LIBERALNOG SKEPTIKA: AMERIČKI ZAPAD I ŽENSKO 'JA' U ŠEPARDOVOM KOMADU LAŽ UMA}

Formiranje i uspostavljenje Sjedinjenih američkih država počiva na dva čvrsta uvjerenja, onom o američkom snu i onom o američkom zapadu. Američki san je, međutim, od samog početka bio dio američke kulture dok je drugi pokretač američke kulture postao tek u drugoj polovini dvadesetog vijeka kada i Sem Šepard započinje svoju karijeru dramskog pisca. U tom je periodu američki teatar postao glavni prostor za reprezentaciju američkog zapada. Ipak, Šepard je u svom prikazu američkog zapada pokušao da izbjegne poigravanje dvostrukošću stvarnosti i iluzije tako što je u prvi plan izveo protagoniste koji se suočavaju sa svijetom kako bi ga iskusili, a onda i otkrili sopstveno 'ja'. Na vrhuncu uspjeha napisao je Laž uma, komad sa velikim brojem junakinja koje su spremne da napuste nasilni muški svijet da bi promijenile sopstvenu sudbinu. Šepard je nastojao da ih kao takve podstakne da se oslobode $i$ iskuse novu stvarnost. Na sličan je način Šepardov savremenik, američki filozof Ričard Rorti vjerovao u važnost 'ja' i neophodnost njegovog preoblikovanja da bi se stvorilo novo društvo. Ipak, ne uspjevajući da pronađe odgovarajući filozofski model on poseže za književnošću, kako bi u njoj pronašao svog liberalnog skeptika. U tom smislu ova studija teži da Sema Šeparda prikaže kao liberalnog skeptika u Rortijevom smislu, ali i da ukaže na određene, međusobno kompatibilne, odlike u Šepardovom komadu Laž uma. Od njih je možda i najznačajnija ta da u potrazi za novom stvarnošću ženski likovi razaraju svijet američkog zapada.

Keywords: američki zapad, kauboj, žensko 'ja' i liberalni skeptik. 